\title{
Inconsistent condom use between serodifferent sexual partnerships to the human immunodeficiency virus*
}

\author{
Renata Karina Reis ${ }^{1}$ \\ (D) https://orcid.org/0000-0002-0681-4721 \\ Elizabete Santos Melo $0^{1,2}$ \\ (iD) https://orcid.org/0000-0002-7322-9370 \\ Nilo Martinez Fernandes ${ }^{3}$ \\ (D) https://orcid.org/0000-0003-3770-6050 \\ Marcela Antonini ${ }^{1,4}$ \\ (1D) https://orcid.org/0000-0003-4711-4788 \\ Lis Aparecida de Souza Neves ${ }^{5}$ \\ (D) https://orcid.org/0000-0001-5255-2649 \\ Elucir Gir $^{1}$ \\ (D) https://orcid.org/0000-0002-3757-4900
}

* Supported by Fundação do Amparo à Pesquisa do Estado de São Paulo (FAPESP), Brazil - Grant \# 2015/23008-2.

Universidade de São Paulo, Escola de Enfermagem de Ribeirão Preto, PAHO/WHO Colaborating Centre for Nursing Research Development, Ribeirão Preto, SP, Brazil.

2 Scholarship holder at the Coordenação de Aperfeiçoamento de Pessoal de Nível Superior (CAPES), Brazil.

3 Fundação Oswaldo Cruz, Instituto de Pesquisa Clínica Evandro Chagas, Rio de Janeiro, RJ, Brazil.

${ }^{4}$ Scholarship holder at the Programa Institucional de Bolsas de Iniciação Científica (PIBIC), Brazil.

5 Prefeitura Municipal de Ribeirão Preto, Programa de Doenças Sexualmente Transmissíveis, Aids, Tuberculose e Hepatites Virais, Ribeirão Preto, SP, Brazil.

\begin{abstract}
Objective: to analyze predictors of inconsistent condom use among HIV-positive people with sexual immunodeficiency virus serodifferent sexual partnership. Method: cross-sectional, analytical study with a consecutive non-probabilistic sample consisting of people living with the human immunodeficiency virus with serodifferent sexual partnership and who were in outpatient clinical follow-up. Data were collected through individual interviews guided by a semi-structured questionnaire and subsequently analyzed with bivariate analysis and logistic regression. Results: Seven variables were independently associated with inconsistent condom use. Schooling less than 11 years of schooling (4.9 [2.4-10.1]), having multiple partnerships (5.0 [1.3-19.6]), using alcohol (2.1 [1.1 -4.4]) or other drugs (2.8 [1.2-6.3]), do not receive advice from a healthcare professional (2.0 [1.1-3.9]), have no knowledge of treatment as prevention $(3.0[1,2-6,9])$ and not knowing that undetectable viral load reduces the risk of human immunodeficiency virus transmission $(3.8[1,1-13,7])$ were predictors for inconsistent condom use. Conclusion: The study showed that psychosocial factors interfere with consistent condom use between serodifferent partnerships. Thus, it is highlighted that there is a need for comprehensive interventions that include the integration of clinical and psychosocial care.
\end{abstract}

Descriptors: Condoms; Unsafe Sex; HIV Infections; Disease Prevention; Nursing Care; HIV Seropositivity.

\section{How to cite this article}

Reis RK, Melo ES, Fernandes NM, Antonini M, Neves LAS, Gir E. Inconsistent condom use between serodifferent sexual partnerships to the human immunodeficiency virus. Rev. Latino-Am. Enfermagem. 2019;27:e3222. [Access ; Available in: DOI: http://dx.doi.org/10.1590/1518-8345.3059.3222. 


\section{Introduction}

The scientific and technological advances regarding the health of people living with HIV (PLHIV), especially in the therapeutic field, with the advent of antiretroviral therapy (ART), caused changes in the life expectancy and perspective of these individuals ${ }^{(1-2)}$.

Thus, the framing of human immunodeficiency virus (HIV) infection as a chronic disease, from access to ART, generated a new paradigm ${ }^{(3)}$ with implications related to the integral health care of these people, since initially, the concern of health services was only to contain the infection.

These changes made it possible for PLHIV to reconstruct their life projects in various aspects, especially in the affective-sexual context, with the establishment of new relationships with sexual partnerships ${ }^{(4)}$, including HIV seronegative.

HIV serodifferent couples - when one partner is HIVpositive and the other HIV-negative(5) - have specific vulnerabilities and are at greater risk of becoming infected with $\mathrm{HIV}^{(6)}$.

In Brazil, despite efforts to interrupt the chain of transmission obtained through the provision of effective antiretroviral therapy, there is still a significant portion of PLHIV that has not reached undetectable viral load (VL), which is one of the factors considered most important for reducing sexual transmission of $\mathrm{HIV}^{(7)}$.

The UNAIDS Joint United Nations Program on HIV / AIDS "cascade" of care projects, by 2030, an ambitious target for the treatment of HIV / AIDS in which $90 \%$ of people are diagnosed with HIV; $90 \%$ of these people get treated and $90 \%$ of them reach viral suppression ${ }^{(8)}$

Data related to the cascade of continuous HIV care in Brazil showed that by the end of 2015 there were 827,000 PLHIV in the country of which 715,000 $(87 \%)$ were diagnosed; $95 \%$ of the diagnosed (677 thousand) had been linked to some health service and $83 \%$ of the linked ( 565 thousand) were retained in this service; $80 \%$ of those retained (455 thousand) were on ART and only $50 \%$ of those on ART ( 410 thousand) had suppressed $\mathrm{VL}^{(9)}$.

Thus, it is noteworthy that it is necessary to advance the fight against the AIDS epidemic in Brazil, because challenges still persist for the approach of sexuality and sexual behavior in the continuous care of PLHIV.

Historically, efforts to prevent infection have focused on reducing the risk of HIV transmission among seronegative individuals or those with unknown serological status and minimizing the needs and important role of PLHIV(10) as if the discovery of infection by itself would ensure changes in the preventive practices and behaviors and vulnerability they faced.
Measures and strategies to prevent sexual transmission of HIV have changed over the course of the epidemic mainly due to scientific advances in the world. The findings defined new forms of prevention that were referred to in Brazil as "combined prevention"(10).

It is the association of behavioral, biomedical and structural intervention strategies ${ }^{(10)}$ focusing on reducing the transmission of HIV infection in various sectors, as it is known that a single prevention strategy is insufficient to control multiple HIV epidemics in the world and in Brazil(6).

It is understood that, in the context of combined prevention, strategies aim to reduce the adherence gaps present in the use of classic preventive methods in isolation, such as the use of only male or female condoms as a preventive method.

To this end, the Ministry of Health has drafted the Combined Prevention Mandala, which outlines all possible strategies that may be effective for preventing HIV infection(11). Thus, during consultations with Specialized Care Services (SCS), users are advised that no single method of prevention can reduce HIV infection ${ }^{(11)}$.

Condoms are considered an important component of the combined approach to HIV prevention and, when used consistently and correctly, are highly effective at preventing sexual transmission of the virus and other sexually transmitted infections (STIs) ${ }^{(11)}$.

In Brazil, condoms are freely distributed by the Unified Health System (UHS) and are a safe, low-cost barrier method with no adverse effects. It should be stimulated among PLHIV in combination with other methods such as treatment as prevention (TPT), pre-exposure prophylaxis (PrEP) and post-exposure prophylaxis $(P E P)^{(11)}$, as inconsistent use increases the risk of HIV reinfection, just as exposure to STI increases the infectivity of the virus and therefore its transmissibility ${ }^{(12)}$.

In this sense, inconsistent male condom use has been described as prevalent among PLHIV with different types of sexual partnerships - both regular and casual, with negative HIV status or unknown HIV status, in different regions of the world(13-19).

However, according to the World Health Organization (WHO), most studies on serodifferent couples have been conducted in sub-Saharan Africa, and knowledge gaps exist in other regions of the world ${ }^{(5)}$, resulting in insufficient emphasis on providing counseling for couples and supporting testing of HIV-positive partners.

In Brazil, some studies (20-21) addressed the relationship of PLHIV in a serodifferent partnership and the use of the male condom, however, they were limited only to evaluate the use and not the factors associated with it. 
Therefore, the aim of this study was to analyze the predictors of inconsistent male condom use among HIVpositive people with HIV-negative sexual partnership.

\section{Method}

This is a cross-sectional and analytical study that was conducted in the five Specialized Care Services (SCS) in a city in the interior of São Paulo.

Participated in the PVHIV study of both sexes, regardless of the stage of HIV infection, which met the inclusion criteria: being aware of the diagnosis of HIV infection; being over 18 years old; being in outpatient clinical follow-up at the services; have an active sex life and sexual partnership regardless of HIV status in the last six months. Those in confinement situations such as persons deprived of liberty and institutionalized, as well as residents of nursing homes, were excluded.

The sampling plan adopted was by simple random sampling in which prevalence parameters were selected by estimating that $62 \%$ of people living with HIV have an active sex life after diagnosis, as described in another study conducted in the municipality ${ }^{(22)}$, relative error of $10 \%$ and significance level of $5 \%$ and a very large total population ( $N=10,000$, for example), which indicated the need for a sample size of 235 . However, to reach this number, 397 PLHIV were interviewed, 286 of whom had HIV serodifferent partnerships.

Data was collected from July 2016 to July 2017 through individual interviews, in specialized outpatient rooms, using a questionnaire built and validated specifically for this data collection. Participants were invited before or after the medical appointment, and the interviews lasted a minimum of 20 and a maximum of 30 minutes and were conducted by five duly trained research assistants.

After a wide search in the literature, it was considered that, in Brazil, until the moment of collection, there were no scales that evaluated the knowledge about the preventive strategies, the beliefs about the infectivity and the sexual transmission of HIV, as well as the preventive behavior of PLHIV. Then, a specific instrument based on national and international literature was elaborated to respond to the objectives of this study, which was submitted to validation as to form and content by three nurses and a psychologist, all specialists in the study theme.

Experts in the area of HIV infection were invited via email to the committee of experts. The process took place by analyzing the instrument as to the general impression, objective, content, relevance, verbal language and inclusion of new questions. After the return, the necessary adjustments were made to achieve the research objectives.

The instrument consisted of sociodemographic variables: age (in years); gender (male, female); education (in complete years of study); profession / occupation; employment relationship (yes or no); color (white, brown, black, indigenous) and clinical: time of diagnosis of HIV infection (in years), plus presence of infectious markers: symptoms of STI (discharge, warts, blisters and genital ulcers) according to Brazilian protocol (6) (yes or no); viral load in the last six months (detectable or undetectable), with a value below 40 copies / $\mathrm{mL}$ considered undetectable.

Regarding the behavioral, practical and knowledge aspects of HIV transmission and counseling about sexual prevention of HIV by the health team, the following behavioral variables were adopted: type of sexual partnership (casual, fixed or casual and fixed); sexual partnership number; alcohol use before sexual intercourse (yes or no); alcohol use during sexual intercourse (yes or no); period of couple formation (before or after the knowledge of HIV infection); HIV serological diagnosis of sexual partnership (seropositive, seronegative or unknown). Belief in sexual transmission of HIV was assessed by the following question: Do you believe that if your viral load is low, you decrease the risk of HIV transmission? (yes / no / don't know), complemented by the questions: did you reveal the diagnosis for the current sexual partnership (yes or no)?; talk to your partner about condom use (yes or no) and male condom use (always, sometimes and never)?

The variables selected to assess the knowledge and advice received by the health care team on HIV sexual prevention were: did you receive guidance on risk of sexual transmission of HIV (yes / no) ?; Looking for information on preventing sexual transmission of HIV? (Yes No)?; Did you receive counseling from your healthcare team about sexual transmission of HIV (yes / no)? Knowledge about the effectiveness of preventive treatment has been assessed by the question: antiretroviral (ARV) treatment, reducing the amount of circulating virus in the body (viral load) and making it undetectable, is effective in preventing HIV transmission to the partner? (yes / no / don't know).

Inconsistent condom use was defined as "yes" for those participants who reported that they never or sometimes used condoms (versus "no", ie "always used condoms") for the past six months.

Data was statistically analyzed using IBM $®$ Statistical Package for Social Sciences (SPSS) software, version 23, and $\mathrm{R}$ ( $\mathrm{R}$ Core Team software, version 3.4.1) software. 
Descriptive statistics were performed to characterize the participants and analytical to verify the association between the study variables through the chi-square test. To assess the influence of independent variables on inconsistent condom use (yes / no), logistic regression analysis was used. The category "yes" was adopted as a reference in all cases. For the analysis, a significance level of $5 \%(a=0.05)$ was adopted.

The study was submitted and appreciated by the Ribeirão Preto Municipal Health Department, which was favorable to its accomplishment. Subsequently, it was submitted to and approved by the Research Ethics Committee of the Ribeirão Preto College of Nursing, following the recommendations of Resolution 466/12 of the National Health Council, under Opinion No. 2,369,369.

\section{Results}

The study included 286 PLHIV who had a serodifferent sexual partnership, with an average age of 41.2 years, ranging from 18 to 73 years. Table 1 shows that the sample consisted predominantly of men $(68.6 \%)$ and of these $37.8 \%$ were men who have sex with men (MSM). It was found that the majority (51.4\%) of respondents had elementary education and about $67.1 \%$ were in the formal or informal job market.

Table 1 - Distribution of people living with HIV* in serodifferent partnership, according to sociodemographic and clinical variables. Ribeirão Preto, SP, Brazil, 2016-2017

\begin{tabular}{|c|c|c|}
\hline Variables & $\mathbf{n}$ & $\%$ \\
\hline \multicolumn{3}{|l|}{ Sexual orientation } \\
\hline Heterosexual woman & 90 & 31.5 \\
\hline Heterosexual man & 88 & 30.8 \\
\hline $\mathrm{MSM}^{\dagger}$ & 108 & 37.8 \\
\hline \multicolumn{3}{|l|}{ Age group (years) } \\
\hline $18-24$ & 23 & 8.0 \\
\hline $25-34$ & 59 & 20.6 \\
\hline $35-44$ & 100 & 35.0 \\
\hline$\geq 45$ & 104 & 36.4 \\
\hline \multicolumn{3}{|c|}{ Education (complete years of study) } \\
\hline$<11$ & 147 & 51.4 \\
\hline$\geq 11$ & 139 & 48.6 \\
\hline \multicolumn{3}{|l|}{ Color } \\
\hline White & 151 & 52.8 \\
\hline Black & 132 & 46.2 \\
\hline \multicolumn{3}{|l|}{ Others } \\
\hline \multicolumn{3}{|l|}{ Work situation } \\
\hline Emloyed & 192 & 67.1 \\
\hline Unemployed & 59 & 20.6 \\
\hline Others & 33 & 11.5 \\
\hline
\end{tabular}

Table 1 - continuation

\begin{tabular}{lcc}
\hline \multicolumn{1}{c}{ Variables } & $\mathbf{n}$ & $\%$ \\
\hline Do not work (on leave) & 02 & 0.7 \\
Family income (minimum wages ${ }^{\ddagger}$ ) & & \\
Up to 1 & 59 & 20.6 \\
2 - 3 & 133 & 46.5 \\
$\geq 3$ & 94 & 32.9 \\
HIV diagnosis time * (years) & & \\
$<2-4.9$ & 105 & 36.7 \\
$\geq 5$ & 181 & 63.3 \\
Infectiousness markers & & \\
STI symptoms ${ }^{-1}$ & & \\
Yes & 40 & 14.0 \\
No & 246 & 86.0 \\
Viral load & & \\
Detectable & & \\
Indetectable & 70 & 24.5 \\
\hline
\end{tabular}

*HIV = Human Immunodeficiency Virus; ${ }^{+}$MSM $=$men who have sex with men; ${ }^{\ddagger}$ minimum wages $=$ minimum wage equivalent to $R \$ 937.00$, in the period from 2016 to 2017, in Brazil; ${ }^{5}$ STI = Sexually Transmitted Infections

It was also identified that $58 \%$ of PLHIV revealed the diagnosis of seropositivity for sexual partnership. Relationships, mostly (74.1\%), were established after the discovery of HIV infection, and approximately half (50.3\%) of participants reported not talking to their partner about condoms.

Among the participants, $72.7 \%$ claimed to have had risky behaviors and practices in the last six months. Of this total, it was found that $44.1 \%$ had sexual intercourse under the influence of alcohol, 34.4\% had sexual intercourse with multiple partners and $29.0 \%$ reported having sex without a condom or making inconsistent use of it, as shown in the table 2.

Table 2 - Distribution of behaviors and practices of people living with HIV* in serodifferent partnership. Ribeirão Preto, SP, Brazil, 2016-2017

\begin{tabular}{lcc}
\hline \multicolumn{1}{c}{ Variables } & N & $\%$ \\
\hline Alcohol use before sexual intercourse & 126 & 44.1 \\
Yes & 160 & 55.9 \\
No & & \\
Drug use before sexual intercourse & 59 & 20.9 \\
Yes & 227 & 79.4 \\
No & 143 & \\
Partner uses alcohol before sexual intercourse & 50.0 \\
Yes & 143 & 50.0 \\
No & & \\
Partner uses drugs before sexual intercourse & 56 & 19.5 \\
Yes & 227 & 79.4 \\
No & (continues...)
\end{tabular}


Table 2 - continuation

\begin{tabular}{lcc}
\hline \multicolumn{1}{c}{ Variables } & N & $\%$ \\
\hline Number of Partners & 179 & 62.6 \\
One & 107 & 34.4 \\
Multiple & & \\
Revealed Diagnosis for Sex Partnership & 166 & 58.0 \\
Yes & 120 & 42.0 \\
No & & \\
Talk to partner about condom use & 142 & 49.7 \\
Yes & 144 & 50.3 \\
No & & \\
Inconsistent condom use & 83 & 29.0 \\
Yes & 203 & 71.0 \\
No & & \\
Met Partner Before HIV Discovered * & 74 & 25.9 \\
Yes & 212 & 74.1 \\
No & & \\
*HIV = Human Immunodeficiency Virus &
\end{tabular}

Table 3 describes the bivariate analysis of sociodemographic and clinical factors associated with inconsistent male condom use among PLWHA who have a serodifferent sexual partnership. Schooling was found to be associated with inconsistent condom use $(p=<0.001)$.
Regarding behavioral variables, it was found that the number of partners $(p=0.048)$, alcohol use $(p=<0.001)$ and other drugs $(p=<0.001)$ during sexual intercourse were associated with inconsistent condom use.

Table 4 also presents another bivariate analysis of the following behavioral variables: knowledge of undetectable viral load in HIV transmission ( $p=<0.001$ ); the search for information on prevention methods on the internet ( $p=0.026)$; not searching for information on prevention methods ( $p=<0.001)$; receiving counseling at the health facility $(p=0.023)$ and talking to a partner about condom use ( $p=<0.001)$ also showed a significant association with inconsistent condom use in HIV-positive women who have an HIV-negative partnership.

In multivariate analysis, seven variables were independently associated with inconsistent condom use. Individuals who reported less than 11 years of schooling (4.9 [2.4-10.1]), have a steady and casual partner (5.0 [1.3-19.6]), use alcohol $(2,1[1.0-4.4])$ or other drugs (2.8 [1.2-6.3]), do not receive counseling from a healthcare professional (2.0 [1.0-3.9]), have no knowledge of treatment as prevention (3.0 [1.2-6.9]) and who do not know if the burden Undetectable viral infection reduces the risk of HIV transmission (3.8 [1.0-13.7]) were predictors for inconsistent condom use, as shown in Table 5.

Table 3 - Sociodemographic and clinical factors associated with inconsistent condom use with HIV-negative sexual partnership* among people living with $\mathrm{HIV}^{+}$. Ribeirão Preto, SP, Brazil, 2016 - 2017

\begin{tabular}{|c|c|c|c|c|}
\hline \multirow[b]{2}{*}{ Variables } & \multicolumn{4}{|c|}{ Condom use with HIV-negative sexual partnership* } \\
\hline & $\begin{array}{l}\text { Consistent } \\
203(71 \%)\end{array}$ & $\begin{array}{c}\text { Inconsistent } \\
83(29.0 \%)\end{array}$ & $\begin{array}{c}\text { Total } \\
286(100)\end{array}$ & p-value \\
\hline \multicolumn{5}{|l|}{ Sexual orientation } \\
\hline Heterosexual woman & $58(28.6)$ & $32(38.6)$ & $90(31.5)$ & \multirow{3}{*}{0.070} \\
\hline Heterosexual man & $60(29.6)$ & $28(33.7)$ & $88(30.8)$ & \\
\hline $\mathrm{MSM}^{\ddagger}$ & $85(41.9)$ & $23(27.7)$ & $108(37.8)$ & \\
\hline \multicolumn{5}{|l|}{ Age group (years) } \\
\hline $18-24$ & $16(7.9)$ & $07(8.4)$ & $23(8.0)$ & \multirow{4}{*}{0.987} \\
\hline $25-34$ & $42(20.7)$ & $17(20.5)$ & $59(20.6)$ & \\
\hline $35-44$ & $70(34.5)$ & $30(36.1)$ & $100(35.0)$ & \\
\hline$\geq 45$ & $75(36.9)$ & $29(34.9)$ & $104(36.4)$ & \\
\hline \multicolumn{5}{|l|}{ Education (years) } \\
\hline$<11$ & $84(41.4)$ & $63(75.9)$ & $147(51.4)$ & \multirow{2}{*}{$<0.001$} \\
\hline$\geq 11$ & $119(58.6)$ & $20(24.1)$ & $139(46.9)$ & \\
\hline \multicolumn{5}{|l|}{ Skin color } \\
\hline White & $102(50.2)$ & $49(61.3)$ & $151(53.4)$ & \multirow{3}{*}{0.147} \\
\hline Black & $20(9.9)$ & $09(11.2)$ & $29(10.2)$ & \\
\hline Others & $81(39.9)$ & $22(27.5)$ & $103(36.4)$ & \\
\hline \multicolumn{5}{|l|}{ HIV diagnosis time $^{\dagger}$ (years) } \\
\hline$<2-4.9$ & $71(35.0)$ & $34(41.0)$ & $105(36.7)$ & \multirow{2}{*}{0.340} \\
\hline$\geq 5$ & $132(65.0)$ & $49(59.0)$ & $181(63.3)$ & \\
\hline \multicolumn{5}{|l|}{ Infectiousness markers } \\
\hline \multicolumn{5}{|l|}{ Viral load } \\
\hline Detectable & $47(23.2)$ & $23(27.7)$ & $70(24.5)$ & \multirow{2}{*}{0.416} \\
\hline Indetectable & $156(76.8)$ & $60(72.3)$ & $216(75.5)$ & \\
\hline \multicolumn{5}{|l|}{ STI symptoms ${ }^{\S}$} \\
\hline Yes & $25(12.3)$ & $15(18.1)$ & $246(86.0)$ & \multirow{2}{*}{0.203} \\
\hline No & $178(87.7)$ & 68 (81.9) & $40(14.0)$ & \\
\hline
\end{tabular}

${ }^{*}$ HIV-negative = Human immunodeficiency virus negative serology; ${ }^{+} \mathrm{HIV}=$ Human Immunodeficiency Virus; ${ }^{\ddagger}$ MSM = men who have sex with men; $\S \mathrm{STI}=$ Sexually Transmitted Infections 
Table 4 - Behavioral, knowledge and counseling factors associated with inconsistent condom use with HIV-negative sexual partnership* of people living with $\mathrm{HIV}^{+}$. Ribeirão Preto, SP, Brazil, 2016 - 2017

\begin{tabular}{|c|c|c|c|c|}
\hline \multirow[b]{2}{*}{ Variables } & \multicolumn{4}{|c|}{ Condom use with HIV-negative sexual partnership* } \\
\hline & $\begin{array}{c}\text { Consistent } \\
203(71.0)\end{array}$ & $\begin{array}{c}\text { Inconsistent } \\
83(29.0)\end{array}$ & $\begin{array}{c}\text { Total } \\
286(100)\end{array}$ & p-value \\
\hline \multicolumn{5}{|l|}{ Partnership Type } \\
\hline Main & $112(55.2)$ & $37(44.6)$ & $149(52.1)$ & \multirow{3}{*}{0.225} \\
\hline Casual & $82(40.4)$ & $40(48.2)$ & $122(42.7)$ & \\
\hline Multiple Partnerships & $09(4.4)$ & $06(7.2)$ & $15(5.2)$ & \\
\hline \multicolumn{5}{|l|}{ Number of Partners } \\
\hline 01 & $136(67.0)$ & $43(51.8)$ & $179(62.6)$ & \multirow{3}{*}{0.048} \\
\hline $02-5$ & $42(20.7)$ & $27(32.5)$ & $69(24.1)$ & \\
\hline$\geq 5$ & $25(12.3)$ & $13(15.7)$ & $38(13.3)$ & \\
\hline \multicolumn{5}{|l|}{ Alcohol use during sex } \\
\hline Yes & $73(36.0)$ & $53(63.9)$ & $126(44.1)$ & \multirow{2}{*}{$<0.001$} \\
\hline No & $130(64.0)$ & $30(36.1)$ & $160(55.9)$ & \\
\hline \multicolumn{5}{|l|}{ Drug use during sex } \\
\hline Yes & $25(12.3)$ & $34(41.0)$ & $59(20.6)$ & \multirow{2}{*}{$<0.001$} \\
\hline No & $178(87.7)$ & $49(59.0)$ & $227(79.4)$ & \\
\hline \multicolumn{5}{|c|}{ Belief about HIV transmission ${ }^{\dagger}$} \\
\hline Yes & $101(49.8)$ & $52(60.2)$ & $153(53.5)$ & \multirow{3}{*}{$<0.001$} \\
\hline No & $98(48.3)$ & $18(21.7)$ & $116(40.6)$ & \\
\hline Don't know & $04(20.0)$ & $13(15.7)$ & $17(5.9)$ & \\
\hline \multicolumn{5}{|c|}{ Search information about prevention methods on the internet } \\
\hline Yes & $90(44.3)$ & $25(30.1)$ & $115(40.2)$ & \multirow{2}{*}{0.026} \\
\hline No & $113(55.7)$ & $58(69.9)$ & $171(58.2)$ & \\
\hline \multicolumn{5}{|c|}{ Does not seek information on prevention methods } \\
\hline Yes & $19(9.4)$ & $29(34.9)$ & $48(16.8)$ & \multirow{2}{*}{$<0.001$} \\
\hline No & $184(90.6)$ & $54(65.1)$ & $238(83.2)$ & \\
\hline \multicolumn{5}{|c|}{ Received advice from healthcare professional } \\
\hline Yes & $29(14.3)$ & $13(15.7)$ & $42(14.3)$ & \multirow{2}{*}{0.023} \\
\hline No & $174(85.7)$ & $67(80.7)$ & & \\
\hline \multicolumn{5}{|l|}{ Revealed diagnosis } \\
\hline Yes & $122(60.1)$ & $44(53.0)$ & $166(58.0)$ & \multirow{2}{*}{0.270} \\
\hline No & $81(39.9)$ & $39(47.0)$ & $120(42.0)$ & \\
\hline \multicolumn{5}{|c|}{ Talk to partner about condom use } \\
\hline Yes & $116(57.1)$ & $26(31.3)$ & $142(49.7)$ & \multirow{2}{*}{$<0.001$} \\
\hline No & $87(42.9)$ & $57(68.7)$ & $144(50.3)$ & \\
\hline \multicolumn{5}{|c|}{ Knowledge about treatment as prevention } \\
\hline Yes & $163(80.3)$ & $50(60.2)$ & $213(74.5)$ & \multirow{3}{*}{0.001} \\
\hline No & $26(12.8)$ & $17(20.5)$ & $43(15.0)$ & \\
\hline Don’t know & $14(6.9)$ & $16(19.3)$ & $30(10.5)$ & \\
\hline
\end{tabular}

*HIV-negative $=$ Human immunodeficiency virus negative serology; ${ }^{+}$HIV $=$Human Immunodeficiency Virus 
Table 5 - Predictors associated with inconsistent condom use among people living with HIV* in serodifferent partnerships. Ribeirão Preto, SP, Brazil, 2016 - 2017

\begin{tabular}{|c|c|c|}
\hline Variables & $\mathrm{aOR}^{\dagger}\left[95 \% \mathrm{Cl}^{\ddagger}\right]$ & p-value \\
\hline \multicolumn{3}{|l|}{ Education (years) } \\
\hline$<11$ & $4.9[2.4-10.1]$ & \multirow{2}{*}{$<0.001$} \\
\hline$\geq 11$ & Ref. $\S$ & \\
\hline \multicolumn{3}{|l|}{ Type of partnership } \\
\hline Main & Ref. $\S$ & \\
\hline Casual & $0.7[0.3-1.4]$ & 0.384 \\
\hline Main and casual & $5.0[1.3-19.6]$ & 0.019 \\
\hline \multicolumn{3}{|l|}{ Alcohol use during sex } \\
\hline Yes & Ref. ${ }^{\S}$ & \multirow{2}{*}{0.034} \\
\hline No & $2.1[1.1-4.4]$ & \\
\hline \multicolumn{3}{|l|}{ Drug use during sex } \\
\hline Yes & Ref.§ & \multirow{2}{*}{0.012} \\
\hline No & $2.8[1.2-6.3]$ & \\
\hline \multicolumn{3}{|c|}{ Received advice from healthcare professional } \\
\hline Yes & Ref. $\S$ & \multirow{2}{*}{0.030} \\
\hline No & $2.0[1.1-3.9]$ & \\
\hline \multicolumn{3}{|c|}{ Knowledge about treatment as prevention } \\
\hline Yes & Ref. $\S$ & \\
\hline No & $3.0[1.2-6.9]$ & 0.010 \\
\hline Don't know & $1.4[0.5-3.7]$ & 0.453 \\
\hline \multicolumn{3}{|c|}{ Knowledge about HIV transmission * } \\
\hline Yes & Ref. $\S$ & \\
\hline No & $0.40[0.20-0.82]$ & 0.012 \\
\hline Don't know & $3.8[1.1-13.7]$ & 0.040 \\
\hline
\end{tabular}

${ }^{*} \mathrm{HIV}=$ Human Immunodeficiency Virus; ${ }^{+} \mathrm{aOR}=$ Adjusted Odds ratio; ${ }^{\ddagger} \mathrm{CI}=$ Confidence Interval; ${ }^{\text {SRef. }}=$ Reference values

\section{Discussion}

In Brazil, there is a lack of official epidemiological and behavioral data on HIV serodifferent couples, in varied contexts of the relationship, either with fixed and / or casual partnerships. This fact highlights its invisibility in services, health policies, as well as between social movements and researchers(23-24).

In this study, it was found that few people (29\%) reported inconsistent condom use with negative or unknown HIV status, which may be corroborated by other investigations that found rates of $28.7 \%$ respectively ${ }^{(22)}$ and $20.7 \%{ }^{(25)}$ of inconsistent condom use among PLHIV.

In fact, although the prevalence of risky sexual behavior decreases after the discovery of HIV infection(17), Studies conducted among PLHIV reported inconsistent condom use with HIV-negative or unknown sex partners in different regions of the

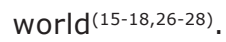

In this sense, it is noteworthy that, in clinical practice, in addition to all the assistance already provided, one should also pay attention to the investigation of behaviors and practices beyond the inconsistent use of condoms, as this is fundamental for the identification of individuals in risk of nonadherence or suboptimal adherence to effective preventive strategies. Other studies have also investigated this issue that may contribute to the risk of HIV transmission to HIV-negative sexual partnership and also reinfection by HIV or acquisition of another STI by HIV-positive partners ${ }^{(27-30)}$.

The results indicate that having a lower educational level was a predictor for inconsistent condom use in the individuals who were part of the study. These results resemble those of other studies, which revealed that a higher level of education is associated with regular condom use ${ }^{(31-32)}$. In addition, another study showed that as the level of education increases, the chance of engaging in risky sexual practices decreases ${ }^{(4)}$.

Low education conditions access to information and the ability to assimilate and understand the guidance received in health services and directly interfere with health behavior and the possibility of adopting protective practices for themselves and others ${ }^{(33)}$.

Better access to information, understanding and awareness about preventing sexual transmission of HIV can foster sexual negotiation and increased condom adherence.

In this study, it was observed that having a casual partner was associated with inconsistent condom use $(p=<0.001)$. And PLHIV who have both fixed and casual partnerships simultaneously are 5.0 times more likely ( $\mathrm{CI}=95 \%, 1.3-19.6, \mathrm{p}=0.019)$ to engage in unprotected sex compared to those who have only single and fixed partnerships. This may be related to the fact that those who have had multiple sexual partners may not disclose their status to their partners, which was also described in a study in Ethiopia(34). Thus, the type of bond and the affectivesexual relationship interfere with condom adherence.

Nursing consultations during the clinical followup of PLHIV should include a comprehensive sexual history approach that includes aspects related to sexual partnerships for the promotion of educational 
interventions and counseling. Health professionals should identify aspects of the relationship and the types of sexual partnerships. Sexual history assessment, which includes the type and number of sexual partnerships, should be a vital part of any health education and counseling session.

A multicenter study of both heterosexual and homosexual serodifferent couples identified 11 cases of HIV transmission among people who had casual partnerships outside of a fixed partnership relationship (35).

Thus, observing HIV transmission outside the relationship with fixed partnerships increases the importance of counseling nurses assessing types of partnerships and inconsistent condom use ${ }^{(13)}$.

Including information about sexual partnerships in risk management and counseling will help to better understand individual risk profiles and to plan appropriate intervention strategies for HIV prevention.

Another predictor found in this study was that using alcohol during sexual intercourse is 2.1 more likely to have unprotected sex with an HIV-serodifferent sexual partnership. This result is in line with several other studies in the literature that have shown the association between alcohol use and risky sexual behavior among PLHIV(36-37). Among serodifferent partnerships, this behavior is particularly worrying, mainly because it exposes seronegative partners to HIV exposure.

Alcohol has been associated with disinhibition in which people may be more likely to engage in riskier sexual behaviors (38). In fact, alcohol use is considered a risk factor for HIV infection because of its interference with adherence to prevention methods such as condoms, impaired ability or willingness to be assertive when negotiating condom use with a resistant partner and decreased perceptions of possible negative consequences of condomless $\operatorname{sex}^{(38)}$.

Systematic review investigating the effects of alcohol consumption on unprotected sexual intentions showed that participants who consumed alcohol were less likely to perform communication and sexual negotiation skills ${ }^{(39)}$.

In addition, alcohol and other drug use is also associated with poor adherence to ART, which may lead to a higher risk of therapeutic failure and, consequently, to sustained non-suppression of viral $\operatorname{load}^{(40-42)}$.
Therefore, interventions directed at the association between alcohol and sexual behavior should highlight the negative influence of alcohol on decision making for protected sex, particularly with occasional partners ${ }^{(43)}$.

For this, health services should offer prevention programs that address coprevalent conditions ${ }^{(44)}$, counseling is needed for people using psychoactive substances, including risk reduction interventions and management of sexual transmission of infection.

Another predictor associated with inconsistent condom use was that health professionals did not receive guidance on preventing sexual transmission of HIV. This result strengthens the importance of health professionals and particularly nurses in reducing inequalities in HIV literacy. Moreover, this result leads to a reflection on the relevance of increasing investments in studies of educational interventions, which allow the establishment of causal relationships between health literacy, prevention literacy and preventive behaviors, so that more effective strategies can be established that are in line with the needs of PLHIV.

The nurse plays an important role in facilitating the communication processes associated with the promotion of health literacy by assessing comprehension, individual motivating factors, barriers to understanding as well as in clear communication with individuals, making health information readable and by adapting the message to their cultural and linguistic needs and promoting more appropriate health decision-making ${ }^{(45)}$.

In this sense, nurses and health staff should implement and evaluate basic health literacy promotion strategies to improve knowledge and skills for adherence to an effective HIV prevention strategy.

The results of this study showed that limited knowledge of PLHIV living in the context of serodiscordance about "treatment as prevention" and misinformation that undetectable viral load does not reduce the risk of HIV transmission were predictors of unprotected sex.

A study in the UK among HIV-affected communities also found that most participants expressed little understanding and confidence in the effect of undetectable viremia on the risk of HIV transmission ${ }^{(46)}$.

In Brazil, a study conducted in the Federal District, which described the perceptions of PLHIV in the 
context of serodiscordance, on the prevention of HIV transmission, identified difficulties in implementing the most recent advances and scientific discoveries in practice. The authors pointed out that, despite the broadening of the range of existing preventive strategies in the context of combined prevention, PLHIV had insufficient knowledge to use new preventive inputs ${ }^{(47)}$, highlighting the importance of disseminating this information in people's daily lives.

Thus, one of the biggest challenges facing these couples relates to knowledge about advances related to HIV prevention, adoption and negotiation of these preventive strategies. Many people living with HIV or even those who are most vulnerable are unaware of the benefits of "treatment as prevention" as a prevention strategy, the concept of combined prevention and risk management of sexual transmission of HIV.

Insufficient knowledge of PLHIV about the use of new prevention tools, including "treatment as prevention", aimed at suppressing CV (undetectable $=$ not transferable) and the use of PrEP or PEP by the HIV-negative partner to compromise the adoption of effective preventive practices by exposing their sexual partnerships to HIV.

In this regard, PLHIV and their sexual partnerships should receive counseling and education with serodifferent couples about these HIV prevention options in isolation or their association with other risk management and prevention methods such as PrEP and condoms ${ }^{(48)}$.

Condoms, when used consistently and correctly, are highly effective at preventing sexual transmission of HIV and other STIs and are considered an important component of a comprehensive approach to HIV prevention ${ }^{(13)}$. Reducing condom use increases the risk of exposure to STIs and HIV infectivity and, therefore, their transmissibility ${ }^{(14)}$.

In the context of combined prevention, the male condom remains a method of protection against STI and HIV infection, and it remains critical to expand its access to the entire population as a priority action (11), especially for people at risk of exposure to HIV and those who are in HIV serodifferent partnership ${ }^{(6)}$.

To this end, it is necessary to overcome the exclusively rational logic of prevention work, which is reflected in a purely prescriptive attitude of condom use, also called "latex fundamentalism", in which it is imposed without the necessary dialogue and reflection for overcoming the difficulties of its use ${ }^{(21)}$.
More innovative approaches that dialogue with the autonomy of PLHIV and their sexual partnerships are needed.

Therefore, considering that prevention options for HIV-serodifferent couples are expanding and becoming more widely available, educational interventions can be a potentially useful tool to help them explore options, make decisions, and identify prevention methods that are best suited to fit their reality and life context ${ }^{(49)}$ and can help PLHIV not only recognize the importance of the male condom, but also to be informed about the existence of other methods that can be combined with the same, enabling them to manage their own risks ${ }^{(11)}$.

Finally, it is noteworthy that this study had some limitations, such as the non-random sample and the fact that information on sexual behavior and condom use was obtained through the patient's report, which may lead to a bias of answer, since it seeks to report what is considered "more correct" than it is actually practiced, which may lead to an underestimation of the risk.

\section{Conclusion}

This study showed that $29 \%$ of PLHIV, in a serodifferent partnership, reported inconsistent condom use. Individual factors - having less education, type of partnership and affective-sexual relationship (multiplicity of sexual partnership); psychosocial - use psychoactive substances, such as alcohol or other drugs, and related to health services - not receiving advice from a healthcare professional, being unaware of treatment as prevention, and unaware that undetectable viral load reduces the risk of HIV transmission were associated with inconsistent condom use.

These results highlight the challenge for HIV prevention and reveal the need for a broader approach to PLHIV care, which includes assessing their sexual partners, desires, fears and difficulties. It is essential that there is a change in current care practice, centered on the biological model, which emphasizes only aspects related to medication adherence and prescriptive condom use.

The male condom, while effective for HIV prevention, is insufficient if used alone to overcome the challenges posed by the epidemic, as important barriers are still observed among PLHIV who have HIVserodifferent sexual partners and are outpatient clinical follow-up in specialized care services. 
Comprehensive health care for these individuals implies the need for comprehensive interventions that include the integration of clinical and psychosocial care, addressing factors that favor non-adherence to preventive strategies and risky behavior, such as alcohol and other drug use.

It is recommended that the health team recognize the urgent need to address the discussion regarding the adoption of alternative proposals for condom use within the context of combined prevention, implementing couple counseling, testing, and support for drug disclosure. HIV diagnosis to sexual partnership, so that the vulnerability of PLHIV seronegative sexual partnerships can be reduced.

\section{References}

1. Tancredi MV, Waldman EA. Survival of AIDS patients in Sao Paulo-Brazil in the pre- and post-HAART eras: a cohort study. BMC Infect Dis. [Internet]. 2014 [cited Sep 5 2018];14 (599):1-8. doi: https://doi.org/10.1186/ s12879-014-0599-8

2. Reis RK, Santos CBD, Dantas RAS, Gir E. Quality of life, sociodemografic factors and sexuality of people living with HIV/AIDS. Texto Contexto Enferm. [Internet]. 2011 [cited Sep 7 2018];20(3):565-75. doi: http:// dx.doi.org/10.1590/S0104-07072011000300019

3. McGrath JW, Winchester MS, Kaawa-Mafigiri D, Walakira E, Namutiibwa F, Birungi J, et al. Challenging the Paradigm: Anthropological Perspectives on HIV as a Chronic Disease. Med Anthropol. [Internet]. 2014 [cited Sep 21 2018];33(4):303-17. doi: https://dx.doi.org/10 $.1080 \% 2 F 01459740.2014 .892483$

4. Tadesse WB, Gelagay AA. Risky sexual practice and associated factors among HIV positive adults visiting ART clinics in public hospitals in Addis Ababa city, Ethiopia: a cross sectional study. BMC Public Health. [Internet]. 2019 [cited Feb 15 2019];28;19(1):113. doi: https:// doi.org/10.1186/s12889-019-6438-5

5. World Health Organization (WHO). Guidance on preexposure oral prophylaxis (PrEP) for serodiscordant couples, men and transgender women who have sex with men at high risk of HIV: recommendations for use in the context of demonstration projects [Internet]. Genebra: WHO; 2012. [cited Sep 21 2018]. Available from: https://www.who.int/hiv/pub/guidance_prep/en/ 6. Ministério da Saúde (BR). Coordenação Nacional DST/ AIDS. Protocolo Clínico e Diretrizes Terapêuticas para Manejo da Infecção pelo HIV em Adultos. [Internet]. Brasília (DF): Ministério da Saúde; 2018. [Acesso 21 set
2018]. Disponível em: http://www.aids.gov.br/pt-br/ pub/2013/protocolo-clinico-e-diretrizes-terapeuticaspara-manejo-da-infeccao-pelo-hiv-em-adultos

7. Patel P, Borkowf CB, Brooks JT, Lasry A, Lansky A, Mermin J. Estimating per-act HIV transmission risk: a systematic review. AIDS. [Internet]. 2014 [cited Sep 20 2018];28(10):1509-18. doi: https://doi.org/10.1097/ QAD.0000000000000298

8. Bones AANS, Costa MR, Cazella SC. The education for facing the HIV Epidemic. Interface. (Botucatu). [Internet]. 2018 [cited Oct 3 2018];22(Supl.1):1457-69. doi: http://dx.doi.org/10.1590/1807-57622017.0066

9. Ministério da Saúde (BR). Coordenação Nacional de DST-Aids. Boletim Epidemiológico Aids - DST [Internet]. Brasília (DF): Ministério da Saúde; 2016. [Acesso 21 set 2018]. Disponível em: http://www.aids.gov.br/pt-br/ pub/2016/boletim-epidemiologico-de-aids-2016

10. Kennedy CE, Medley AM, Sweat MD, O'Reilly KR. Behavioural interventions for HIV positive prevention in developing countries: a systematic review and metaanalysis. Bull World Health Organ. [Internet]. 2010 [cited Sep 5 2018];88(8):615-23. doi: https://doi. org/10.2471/BLT.09.068213

11. Ministério da Saúde (BR). Prevenção combinada do HIV - bases conceituais para profissionais, trabalhadores(as) e gestores(as) de saúde [Internet]. Brasília (DF): Ministério da Saúde; 2017. [Acesso 21 set 2018]. Disponível em: http://www.aids.gov.br/ pt-br/pub/2017/prevencao-combinada-do-hiv-basesconceituais-para-profissionais-trabalhadoresas-egestores

12. Dourado I, Mccarthy S, Reddy M, Calazans G, Gruskin S. Revisiting the use of condoms in Brazil. Rev Bras Epidemiol. [Internet]. 2015 [cited Sep 7 2018];18(1):63-88. doi: https://doi.org/10.1590/18094503201500050006

13. Koff A, Goldberg C, Ogbuagu O. Condomless sex and HIV transmission among serodifferent couples: current evidence and recommendations. Ann Med. [Internet]. 2017 [cited Sep 7 2018]; 49(6):534-44. doi: https:// doi.org/10.1080/07853890.2017.1320423

14. Kalichman SC, Cherry C, Kalichman MO, Amaral CM, White $\mathrm{D}$, Pope $\mathrm{H}$. Integrated behavioral intervention to improve HIV/AIDS treatment adherence and reduce HIV transmission. Am J Public Health. [Internet]. 2011 [cited Sep 5 2018];101(3):531-8. doi: https://doi. org/10.2105/AJPH.2010.197608

15. Mattson $\mathrm{CL}$, Freedman M, Fagan JL, Frazier EL, Beer $L$, Huang $P$, et al. Sexual risk behaviour and 
viral suppression among HIV-infected adults receiving medical care in the United States. AIDS. [Internet]. 2014 [cited Sep 10 2018];28(8):1203-11. doi: https:// doi.org/10.1097/QAD.0000000000000273

16. Bavinton BR, Holt M, Grulich AE, Brown G, Zablotska IB, Prestage GP. Willingness to Act upon Beliefs about "Treatment as Prevention" among Australian Gay and Bisexual Men. PLoS One. [Internet]. 2016 [cited Sep 7 2018];11(1):e0145847. doi: https:// doi.org/10.1371/journal.pone.0145847

17. Du $P$, Crook T, Whitener $C$, Albright $P$, Greenawalt $D$, Zurlo J. HIV Transmission Risk Behaviors among People Living with HIV/AIDS: The Need to Integrate HIV Prevention Interventions and Public Health Strategies into HIV Care. J Public Health Manag Pract. [Internet]. 2015 [cited Sep 17 2018];21(2):1-10. doi: https://doi. org/10.1097/PHH.0000000000000038

18. Kramer SC, Drewes J, Kruspe M, Marcus U. Factors associated with sexual risk behaviors with non-steady partners and lack of recent HIV testing among German men who have sex with men in steady relationships: results from a cross-sectional internet survey. BMC Public Health. [Internet]. 2015 [cited Sep 5 2018];15:702. doi: https://doi.org/10.1186/s12889-015-1987-8

19. Deuba K, Kohlbrenner V, Koirala S, Ekström AM. Condom use behaviour among people living with HIV: a seven-country community-based participatory research in the Asia-Pacific region. Sex Transm Infect. [Internet]. 2018 [cited Oct 3 2018];94(3):200-5. doi: https://doi. org/10.1136/sextrans-2017-053263

20. Hallal RC, Raxach JC, Barcellos NT, Maksud I. Strategies to prevent HIV transmission to serodiscordant couples. Rev Bras Epidemiol. [Internet]. 2015 [cited Oct 3 2018];18(supp.1):169-82. doi: https://doi. org/10.1590/1809-4503201500050013

21. Fernandes NM, Hennington EA, Bernardes JS, Grinsztejn BG. Vulnerability to HIV infection in serodiscordant couples in Rio de Janeiro, Brazil. Cad Saúde Pública. [Internet]. 2017 [cited Oct 3 2018]; 33(4):e00053415. doi: https://doi.org/10.1590/0102$311 \times 00053415$

22. Reis RK, Melo ES, Gir E. Factors associated with inconsistent condom use among people living with HIV/ Aids. Rev Bras Enferm. [Internet]. 2016 [cited Sep 14 2018];69(1):47-53. doi: http://dx.doi.org/10.1590/0034$7167.2016690106 i$

23. Silva AM, Camargo Junior KR. The invisibility of serodiscordance in care for people with HIV/AIDS. Ciênc Saúde Coletiva. [Internet]. 2011 [cited Sep 5
2018];16(12):4865-74. doi: http://dx.doi.org/10.1590/ S1413-81232011001300035

24. Lago ELM, Maksud I, Gonçalves RS. The "Serodiscordance" for Health Professionals: A Qualitative Study of Ambulatory Care of HIV/AIDS in the Municipality of the State of Rio de Janeiro. Temas Psicol. [Internet]. 2013 [cited Sep 5 2018];21(3):973-88. doi: http:// dx.doi.org/10.9788/TP2013.3-EE11PT.

25. Silva WS, Oliveira FJF, Serra, MAAO, Rosa CRDAA, Ferreira AGN. Factors associated with condom use in people living with HIV/AIDS. Acta Paul Enferm. [Internet]. 2015 [cited Sep 17 2018];28(6):587-92. doi: http://dx.doi.org/10.1590/1982-0194201500096 26. Magidson JF, Biello KB, Safren SA, Rosenberger JG, Novak DS, Mayer KH, et al. Engagement in HIV care and sexual transmission risk behavior among men who have sex with men using online social/sexual networking in Latin America. AIDS Care. [Internet] 2015 [cited Sep 17 2018];27(8):1055-62. doi: https://doi.org/10.1080/09 540121.2015 .1017796

27. Kalichman SC, Cherry C, Kalichman MO, Washington C, Grebler T, Hoyt G, et al. Sexual Behaviors and Transmission Risks among People Living with HIV: Beliefs, Perceptions, and Challenges to Using Treatments as Prevention. Arch Sex Behav. [Internet]. 2016 [cited Sep 17 2018];45(6):1421-30. doi: https:// doi.org/10.1007/s10508-015-0559-4

28. Molla AA, Gelagay AA. Risky sexual practice and associated factors among HIV positive adults attending anti-retroviral treatment clinic at Gondar University Referral Hospital, Northwest Ethiopia. PLoS One. [Internet]. 2017 [cited Sep 5 2018];12(3):e0174267. doi: https://doi.org/10.1371/journal.pone.0174267

29. Lampe FC. Sexual behaviour among people with HIV according to self-reported antiretroviral treatment and viral load status. AIDS. [Internet]. 2016 [cited Sep 5 2018];30(11):1745-59. doi: https://doi.org/10.1097/ QAD.0000000000001104

30. Davey DJ, Kilembe W, Wall KM, Khu NH, Brill I, Vwalika B, et al. Risky Sex and HIV Acquisition Among HIV Serodiscordant Couples in Zambia 2002-2012: What Does Alcohol Have To Do With It? AIDS Behav. [Internet]. 2017 [cited Sep 20 2018];21(7):1892-903. doi: https://doi.org/10.1007/s10461-017-1733-6

31. Shewamene Z, Legesse B, Tsega B, Bhagavathula AS, Endale A. Consistent condom use in HIV/AIDS patients receiving antiretroviral therapy in northwestern Ethiopia: implication to reduce transmission and multiple infections. HIV AIDS. (Auckl). [Internet]. 2015 [cited 
Sep 17 2018];7:119-24. doi: https://doi.org/10.2147/ HIV.S79122

32. Pilapil M, Morris L, Saito K, Kouya F, Maku V, Kwalar R, et al. Retrospective analysis of the prevalence of and factors associated with condom use among young HIVinfected women in Cameroon. SAGE Open Med. [Internet]. 2016 [cited Sep 3 2018]; 4:2050312115626432. doi: https://doi.org/10.1177/2050312115626432

33. Takahashi LM, Magalong MG, Debell P, Fasudhani A. HIV and AIDS in suburban Asian and Pacific Islander communities: factors influencing self-efficacy in HIV risk reduction. AIDS Educ Prev. [Internet] 2006 [cited Sep 3 2018];18(6):529-45. doi: https://doi.org/10.1521/ aeap.2006.18.6.529

34. Mosisa G, Woldemichael K, Ayalew F. Risky sexual behavior and associated factors among antiretroviral therapy attendees in Nekemte Referral Hospital, Western Ethiopia: a cross-sectional study. HIV AIDS. (Auckl). [Internet] 2018 [cited Sep 3 2018];10:125-31. doi: https://dx.doi.org/10.2147\%2FHIV.S159670

35. Rodger AJ, Cambiano V, Bruun T, Vernazza $P$, Collins S, Van Lunzen J, et al. Sexual activity without condoms and risk of HIV transmission in serodifferent couples when the HIV-positive partner is using suppressive antiretroviral therapy. JAMA. [Internet]. 2016 [cited Sep 17 2018]; 316(2):171-81. doi: https:// doi.org/10.1001/jama.2016.5148

36. Bajunirwe F, Bangsberg DR, Sethi AK. Alcohol use and HIV serostatus of partner predict high-risk sexual behavior among patients receiving antiretroviral therapy in South Western Uganda. BMC Public Health. [Internet] 2013 [cited Sep 18 2018];3;13:430. doi: https://doi. org/10.1186/1471-2458-13-430

37. Papas RK, Gakinya BN, Mwaniki MM, Wu XK, Lee H, Martino S, et al. Associations with Unprotected Sexual Behavior Among HIV-Infected Drinkers in Western Kenya. AIDS Behav. [Internet] 2018 [cited Dec 12 2018];22(9):2840-50. doi: https://doi.org/10.1007/ s10461-018-2150-1

38. Wray TB, Celio MA, Pérez AE, DiGuiseppi GT, Carr DJ, Woods LA, et al. Causal Effects of Alcohol Intoxication on Sexual Risk Intentions and Condom Negotiation Skills Among High-Risk Men Who Have Sex with Men (MSM). AIDS Behav. [Internet] 2019 [cited Feb 2 2019];23(1):161-74. doi: https://doi.org/10.1007/ s10461-018-2243-x

39. Scott-Sheldon LA, Carey KB, Cunningham K, Johnson BT, Carey MP, \& MASH Research Team. Alcohol Use Predicts Sexual Decision-Making: A Systematic
Review and Meta-Analysis of the Experimental Literature. AIDS Behav. [Internet]. 2016 [cited Set 20 2018];20(Suppl.1):S19-39. doi: https://doi. org/10.1007/s10461-015-1108-9

40. Garin N. Prevalence and clinical impact of recreational drug consumption in people living with HIV on treatment: a cross-sectional study. BMJ Open. [Internet]. 2017 [cited Sep 5 2018]; 7(1):e014105. doi: https://doi.org/10.1136/bmjopen-2016-014105

41. Kalichman SC, Grebler T, Amaral CM, McNerney M, White D, Kalichman MO et al. Viral Suppression and Antiretroviral Medication Adherence Among Alcohol Using HIV Positive Adults. Int J Behav Med. [Internet]. 2014 [cited Sep 20 2018];21(5):811-20. doi: https:// doi.org/10.1007/s12529-013-9353-7

42. Paolillo EW, Gongvatana A, Umlauf A, Letendre SL, Moore DJ. At-Risk Alcohol Use is Associated with Antiretroviral Treatment Nonadherence Among Adults Living with HIV/AIDS. Alcohol Clin Exp Res. [Internet]. 2017 [cited Sep 5 2018];41(8):1518-25. doi: https:// doi.org/10.1111/acer. 13433

43. Wells BE, Rendina HJ, Kelly BC, Golub SA, Parsons JT. Demographic Predictors of Event-Level Associations between Alcohol Consumption and Sexual Behavior. J Urban Health. [Internet]. 2016 [cited Sep 3 2018];93(1):155-69. doi: https://doi.org/10.1007/ s11524-015-0015-8

44. Mimiaga MJ, White JM, Krakower DS, Biello KB, Mayer KH. Suboptimal awareness and comprehension of published preexposure prophylaxis efficacy results among physicians in Massachusetts. AIDS Care. [Internet]. 2014 [cited Oct 10 2018];26(6):684-93. doi: https://doi.org/10.1080/09540121.2013.845289

45. Speros CI. Promoting health literacy: a nursing imperative. Nurs Clin North Am. [Internet]. 2011 [cited Sep 5 2018];46(3):321-33. doi: https://doi. org/10.1016/j.cnur.2011.05.007

46. Young I, Flowers P, Mcdaid LM. Key factors in the acceptability of treatment as prevention (TasP) in Scotland: a qualitative study with communities affected by HIV. Sex Transm Infect. [Internet]. 2015 [cited Sep 17 2018];91(4):269-74. doi: https://doi. org/10.1136/sextrans-2014-051711

47. Said AP, Seidl EMF. Serodiscordance and prevention of HIV: perceptions of individuals in stable and nonstable relationships. Interface. (Botucatu). [Internet]. 2015 [cited Set 20 2018]; 19(54):467-78. doi: http:// dx.doi.org/10.1590/1807-57622014.0120 
48. Nakku-Joloba E, Pisarski EE, Wyatt MA, Muwonge TR, Asiimwe $\mathrm{S}$, Celum $\mathrm{CL}$, et al. Beyond HIV prevention: everyday life priorities and demand for PrEP among Ugandan HIV serodiscordant couples. J Int AIDS Soc. [Internet] 2019 [cited Feb 12 2019]; 22(1): e25225. doi: https://dx.doi.org/10.1002\%2Fjia2.25225

49. Zajac K, Kennedy CE, Fonner VA, Armstrong KS, O'Reilly KR, Sweat MD. A Systematic Review of the Effects of Behavioral Counseling on Sexual Risk Behaviors and HIV/STI Prevalence in Low- and MiddleIncome Countries. AIDS Behav. [Internet]. 2015 [cited Sep 5 2018];19(7):1178-202. doi: https://dx.doi. org/10.1007\%2Fs10461-014-0893-x Creative Commons (CC BY).

This license lets others distribute, remix, tweak, and build upon your work, even commercially, as long as they credit you for the original creation. This is the most accommodating of licenses offered. Recommended for maximum dissemination and use of licensed materials. 